\title{
THE EFFECT OF ANTENATAL CLASS ON BIRTH AND PARENTING PREPAREDNESS: A PATH ANALYSIS EVIDENCE FROM SALATIGA, CENTRAL JAVA
}

\author{
Ana Yuliana'), Bhisma Murti'1), Hanung Prasetya') \\ 1) Masters Program in Public Health, Universitas Sebelas Maret \\ 2)Department of Acupuncture, School of Health Polytechnics, \\ Ministry of Health Surakarta
}

\begin{abstract}
Background: Antenatal classes, also called birth and parenting classes, help mothers to get ready for labor, birth, breastfeeding, and caring for a new born baby. It helps mothers to feel more confident as the birth approaches. This study aimed to examine the effect of antenatal class on maternal birth and parenting preparedness.

Subjects and Method: This was an analytic observational study with a crosssectional design. The study was conducted in Salatiga, Central Java, from March 28 to June 26,2018 . A sample of 120 pregnant women was selected for this study by fixed disease sampling. The dependent variables were birth and parenting preparedness. The independent variables were motivation, prenatal class, and health personnel support. The data were collected by questionnaire and analyzed by path analysis.

Results: Birth and parenting preparedness directly increased with prenatal class $(b=4.36 ; 95 \% \mathrm{CI}=1.10$ to $7.01 ; \mathrm{p}=0.009)$, motivation $(\mathrm{b}=0.29 ; 95 \% \mathrm{CI}=-$ 0.03 to $0.61 ; \mathrm{p}=0.077)$, and health personnel support $(\mathrm{b}=5.02 ; 95 \% \mathrm{CI}=0.46$ to 6.05; $\mathrm{p}=0.002)$. Birth and parenting preparedness was indirectly affected by motivation trough prenatal class.

Conclusion: Birth and parenting preparedness directly increases with prenatal class, motivation, and health personnel support. It is indirectly affected by motivation.
\end{abstract}

Keywords: birth and parenting preparedness, prenatal class, motivation, health personnel support

\section{Correspondence:}

Ana Yuliana. Masters Program in Public Health, Universitas Sebelas Maret, Jl. Ir. Sutami No. 36 A, Surakarta 57126, Central Java.

Email: aishabilqisnugroho@gmail.com. Mobile: 081393215435. 